\title{
JAUNESNIOJO MOKYKLINIO AMŽIAUS MERGAIČIŲ ŠOKLUMO KAITA PER DU MĖNESIUS
}

\author{
Eduardas Rudas, Albertas Skurvydas \\ Lietuvos kūno kultūros akademija, Kaunas, Lietuva
}

\begin{abstract}
Eduardas Rudas. Biologijos krypties doktorantas. Lietuvos kūno kultūros akademijos Jungtinės sporto šakų ir rekreacijos katedros asistentas. Mokslinių tyrimų kryptis - jaunesniojo mokyklinio amžiaus vaikų šoklumo judesių kaita.
\end{abstract}

\section{SANTRAUKA}

Tirta jaunesniojo mokyklinio amžiaus ketvirtu klasiu (10 0,5 metu) mergaičiu šoklumo kaita. Buvo tiriama 17 ketvirtos klasès mergaičiu. Tikslas - nustatyti, kaip kinta jaunesniojo mokyklinio amžiaus mergaičiu du mènesius ugdomas šoklumas.

Šoklumas ugdytas du kartus per savaitę. Treniruotès metu po neintensyvios 10 minučiu pramankštos tiriamosios kas 30 sekundžiu atliko po 50 šuoliu. Rekomenduota šokti kiek galima aukščiau. Šuolio aukščiui nustatyti naudota kontaktine platforma, sujungta su elektroniniu šuolio aukščio ir atsispyrimo laiko matuokliu. Moksleiviu šuoliai užrašomi asmeniniame protokole. Tyrimo rezultatai apdoroti matematinès statistikos metodais.

Atlikus tyrima nustatyta, kad mergaičiu šoklumas dèl treniruočiu reikšmingai pagerejo, lyginant su pirma treniruote. Rezultatu prieaugio skirtumas statistiškai patikimas. Paaiškèjo, kad mergaičiu šuoliu rezultatai gerèjo tolygiai. Dèl treniruočiu padidejo ir moksleiviu šoklumo rezultatu vidurkiu sklaida. Tyrimas parodè, kad pagal pirmos treniruotès vertikalaus šuolio rezultatu vidurkị negalima prognozuoti galutiniu šoklumo rezultatu.

Raktažodžiai: šuoliai, raumenu nuovargis, fizinis ugdymas.

\section{IVADAS}

$\mathrm{S}$ portinejje praktikoje naudojama nemažai pratimų, biodinamine struktūra panašių i šuolius, kurių atlikimo metu realizuojama raumenų staigioji jèga. Dažnai sportininkas, kurio staigiosios jègos rodikliai nèra labai geri, yra pakankamai šoklus (Skurvydas, 1988). Šoklumas priklauso nuo daugelio specifinių griaučiu raumenų funkcinių savybių, jų kompozicijos, t. y. nuo greitujų ir lètujų raumeninių skaidulų procentinès sudèties, nuo elastinių ir mioelektrinių raumens savybių panaudojimo amortizacinių pratimų metu. I jas dar 1970 metais demesi atkreipé J. V. Verchošanskis. Šoklumas ir greitumas - vyraujantys kompleksiniai motoriniai ịvairių šakų sportininkų gebejjimai (Balsom et al., 1992; Skurvydas ir kt.,1995). Raumenų susitraukimo efektyvumas priklauso nuo daugelio fiziologinių, biocheminiu veiksnių, kuriuos lemia ne tik motorinès sistemos lavejimas ir brendimas (Malina, Bouchard, 1991), bet ir treniruočių krūviai (Häkkinen, 1994; Mamkus, 1998; Stanislovaitis, 1998). Šoklumas gerèja organizmui augant ir bręstant, todèl labai svarbus yra paauglystės laikotarpis (Malina, 1991; Brin et a1., 1994; Spirduso, 1995). Šis tarpsnis sutampa su didejančiu motoriniu aktyvumu, taip pat spartesniu motorikos lavejjimu natūralaus brendimo 
laikotarpiu (Jaščaninas ir kt., 1989; Malina and Bouchard, 1991; Kraemer and Fleck, 1993). Paaugliu judejjimo reakcijos absoliutus greitis padidèja 8-12 metais (Karoblis, 1999). Literatūroje randama duomenų, kad jaunas organizmas geba „plastiškai“ adaptuotis prie pratybų krūvio (Malina and Bouchard, 1991; Komi, 1992; Kraemer and Fleck, 1993), tačiau neaišku, kokie krūviai, ju struktūra, apimtis ir intensyvumas turètų būti optimalūs, t. y. skatintų, o ne slopintų natūralaus augimo ir brendimo tempus. Tinkamiausias amžius greitumui ugdyti - 9-13 metai (Karoblis, 1999). Kai kuriu autoriu tyrimu duomenimis, ilgos trukmès krūviai gali lemti greitai susitraukiančių (greitujų) raumeninių skaidulų transformavimąsi i lètai susitraukiančias (lètąsias) raumenines skaidulas (Booth \& Thomason, 1991; Salmons, 1994).

Šoklumo ugdymo priemonių ir metodų efektyvumą nagrinejja daugelis mokslininkų (Malina and Bouchard, 1991; Komi,1992; Kraemer and Fleck, 1993; Häkkinen, 1994; Mamkus, 1998; Stanislovaitis, 1998). Iškyla gausybė klausimų, kaip šoklumą ugdančius pratybų krūvius paskirstyti optimaliai ir pasiekti stabilesnių šoklumo rodiklių. Ugdant šoklumą, turètų gerèti greitumo ir raumenu galingumo rodikliai. Sporto pedagogai ir mokslininkai, remdamiesi organizmo adaptacijos dessningumais, taiko keletą pagrindinių sporto treniruotès krūvio planavimo sistemų, kurios skiriasi krūvių paskirstymu ir jų atlikimo specifika (Komi, 1992; Enoka, 1994; Wilmore \& Costill, 1994; Karoblis, 1999). Neaišku, kaip šoklumą ugdantys krūviai per du mènesius paveikia jaunesniojo mokyklinio amžiaus moksleivių (mergaičių) šoklumą.

Tyrimo tikslas - nustatyti, kaip kinta jaunesniojo mokyklinio amžiaus mergaičių $(10 \pm 0,5$ metų) du mėnesius ugdomas šoklumas.

Hipotezè. Remiantis organizmo adaptacijos prie fizinių krūvių biologiniais dèsningumais (Balsom et al., 1992; Glenmark et al., 1992; Komi, 1992), galima daryti prielaida, kad 8 savaites šoklumą ugdantys krūviai didins šoklumo rodiklius.

\section{TYRIMO METODAI IR ORGANIZAVIMAS}

Šoklumo testavimas. Vienkartiniai vertikalūs šuoliai buvo fiksuojami naudojant LKKA žmogaus motorikos laboratorijoje aprobuotus metodus
(Stanislovaitis, 1998; Mamkus, 1998; Zachovajevas, 1998). Šuoliams matuoti buvo naudojama kontaktinè platforma $60 \times 60 \mathrm{~cm}$, laidais sujungta su elektroniniu šuolio aukščio ir atsispyrimo laiko matuokliu. Šuolio aukštis buvo nustatomas pagal lèkimo fazès trukmę. Lèkimo trukmè perskaičiuojama į šuolio aukštị, naudojant formulę (Bosco et al., $1983 \mathrm{a}, \mathrm{b})$ :

$$
h=\frac{g \times t_{p}^{2}}{8}=1,22625 \times t_{p}^{2},
$$

čia: $\mathrm{h}$ - šuolio aukštis (m);

$\mathrm{g}$ - laisvo kritimo pagreitis $\left(9,80665 \mathrm{~m} / \mathrm{s}^{2}\right)$;

$\mathrm{t}_{\mathrm{p}}$ - lèkimo trukmè (s).

$\breve{S}^{\mathrm{p}}$ uoliai atliekami amortizuojamai pritupiant iki $90^{\circ}$ (hp 90) kampo per kelius (kampas kontroliuojamas stebint), rankų padètis - ant juosmens, šuoliuojama vertikaliai aukštyn (1 pav.).

Matematinè statistika. Vertikalių šuolių rezultatai buvo apdoroti matematinès statistikos metodais apskaičiuojant:

- aritmetini vidurkí;

- vidutini kvadratini nuokrypi;

- procentinę rezultatu kaitą;

- skirtumo tarp aritmetinių vidurkių reikšmingumą pagal dvipusi Stjudento $t$ kriterijų (aritmetinių vidurkių skirtumo reikšmingumo lygmuo buvo laikomas svarbiu, kai paklaida $(\mathrm{p}<0,05)$ mažesnè nei $5 \%$;

- ryši tarp rodikliu — buvo taikomas Pirsono koreliacijos koeficientas.

Tiriamieji. Palemono vidurinès mokyklos normaliai išsivysčiusios ir sveikos mergaitès $(\mathrm{n}=17)$. Jų amžius $-10 \pm 0,5$ metu, ùgis $143,0 \pm 5,7 \mathrm{~cm}$, svoris $-33,4 \pm 5,1$. Visos jos mokèsi ketvirtoje klasejje.

Tyrimo organizavimas. Moksleivès ugdè šoklumą 8 savaites (du kartus per savaitę, pirmoje dienos dalyje, iki pietu). Tiriamosios po 10 minučių neintensyvios pramankštos (tempimo pratimų, lèto bègimo (pulsas bėgimo pabaigoje iki 110120 tvinksniu per minutę), lengvų šuoliukų) ant kontrolinès platformos atliko vertikalius šuolius, amortizuojamai pritūpdamos per kelių sąnarius iki

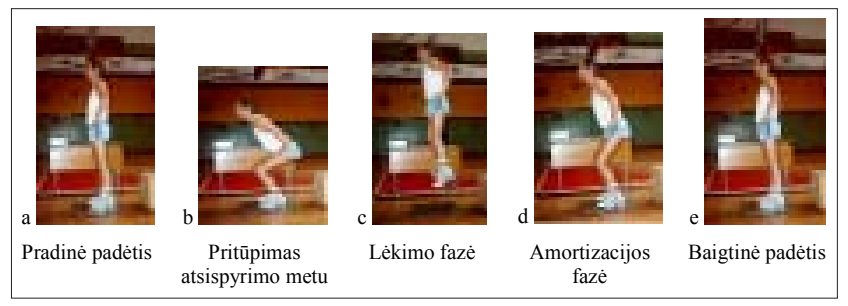

1 pav. Šuolių atlikimo technika 
$90^{\circ}$ kampo. Ranku padetis - ant juosmens. Remiantis C. Bosco ir P. Komi (1979) metodika, buvo apskaičiuojamas vertikalaus šuolio aukštis (h). Per vieną treniruočių dieną kiekviena mergaitè atlikdavo po 50 vertikalių šuolių. Intervalai tarp šuolių — 30 sekundžių. Rekomenduota šuolị atlikti kiek įmanoma aukščiau, stengiantis pagerinti asmeninį rezultatą.

Vertikalūs šuoliai buvo fiksuojami užrašant kiekvieno šuolio aukštị i asmeninị kiekvienos moksleivès protokolą.

\section{TYRIMO REZULTATAI}

Tirtų mergaičiu amžiaus, ūgio ir svorio parametrai pateikti lenteleje. 8 savaites ugdant mergaičių šoklumą (buvo atliekama po 50 šuolių kas 30 s maksimaliai pašokant), šuolių vidurkiai nuosekliai didèja. Iš rezultatų, pateiktų 2 paveiksle, matyti, kad tiriamujų šuolių vidurkių rezultatas po 15 treniruočiu pagerèja nuo 21,2 iki 27,5 cm -

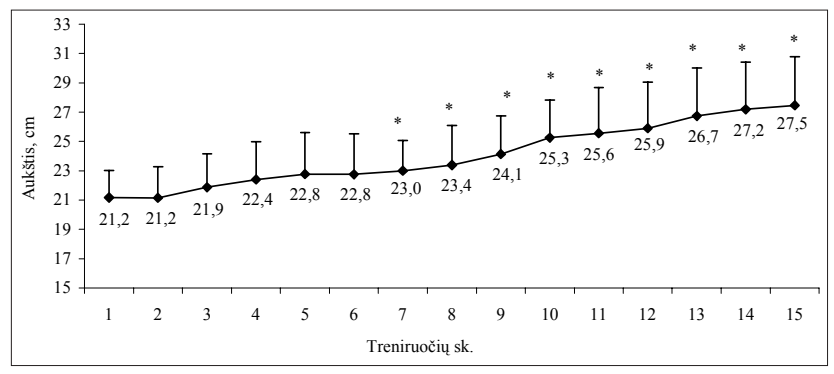

2 pav. Mergaičių vertikalių šuolių rezultatų vidurkis (* $\mathbf{p}<\mathbf{0 , 0 5 )}$

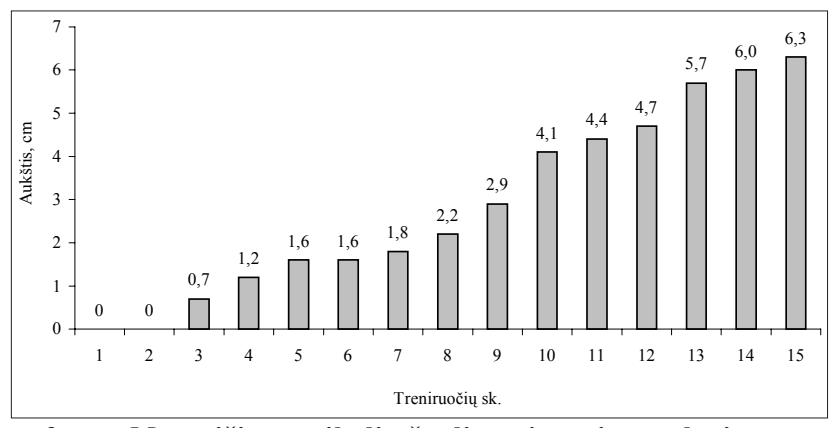

3 pav. Mergaičių vertikalių šuolių prieaugis $\mathbf{c m}$, lyginant su pirma treniruote

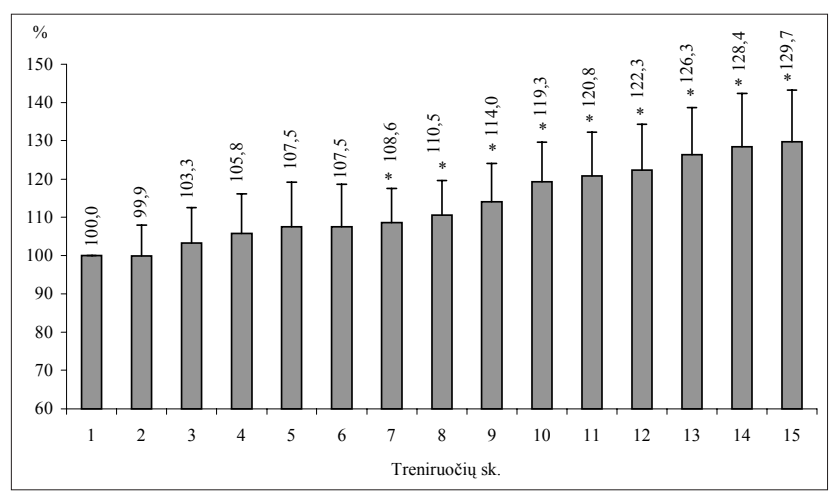

4 pav. Mergaičių šuolių vidurkių procentinė kaita, lyginant su pirma treniruote $(*-p<0,05)$
Lentelè. Mergaičių amžiaus, ūgio ir svorio parametrai

\begin{tabular}{|c|c|c|c|}
\hline Rodiklis & Amžius, m. & Ūgis, $\mathrm{cm}$ & Svoris, $\mathrm{kg}$ \\
\hline Vidurkis & $10 \pm 0,5$ & $143,4 \pm 5,7$ & $33,4 \pm 5,1$ \\
\hline
\end{tabular}

daugiau kaip $6 \mathrm{~cm}$. Vertikalių šuolių aritmetiniu vidurkių analizè rodo pamažu gerèjančius šuolių rodiklius. Rezultatai skiriasi nereikšmingai iki šeštos treniruotès. Skirtumas statistiškai patikimas $(\mathrm{p}<0,05)$ nuo septintos treniruotès, ją lyginant su pirma. Mergaičių šuolių rezultatai treniruojantis gerèja lètai, bet tolygiai.

Išanalizavus mergaičių rezultatų gerèjimo spartą ir palyginus su pirma treniruote ( 3 pav.) matyti, kad rezultatai nuosekliai kyla. Tik 1 ir 2, bei 5 ir 6 treniruotès šuolių rezultatų vidurkiai buvo maždaug vienodi, visi kiti rezultatai mergaitems reguliariai treniruojantis pamažu gereja.

Stebint mergaičių šuolių rezultatų vidurkių procentinès išraiškos kaitą, 4 paveiksle matyti, kad procentinè šuoliu išraiška, lyginant su pirma treniruote, nuolatos didèja. Šuolių rezultatų prie-

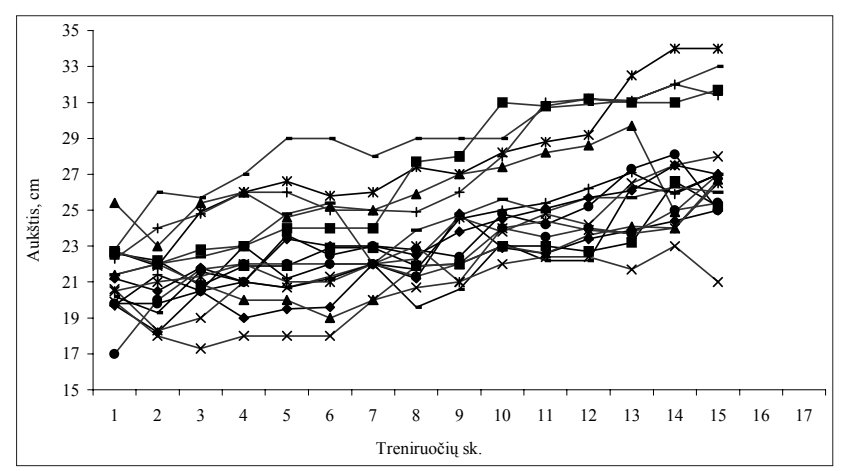

5 pav. Mergaičių vertikalių šuolių rezultatų vidurkių sklaida

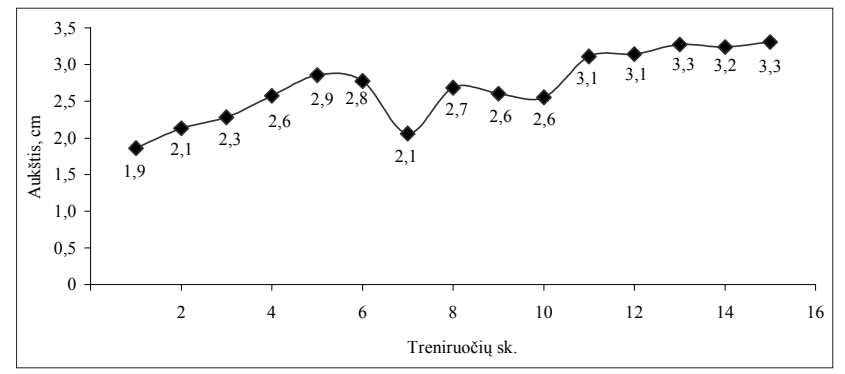

6 pav. Mergaičių standartinio nuokrypio kreivè

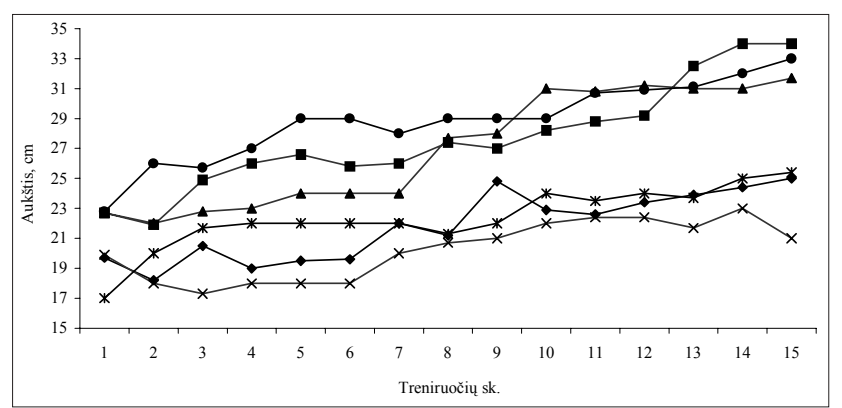

7 pav. Trys geriausi ir trys blogiausi mergaičių šuolių rezultatai 
augis po šoklumo ugdymo sudaro apie 30 procentu, lyginant su pirma treniruote. Skirtumas po šoklumo ugdymo treniruočiu statistiškai patikimas $(*-\mathrm{p}<0,05)$.

Mergaitèms treniruojantis, jų šuolių aukščio rezultatų vidurkių sklaidos diapazonas išsiplète (5 pav.). Pirmos treniruotès šuolių rezultatų vidurkių sklaida $-8,4 \mathrm{~cm}$ (nuo 17 iki $25,4 \mathrm{~cm}$ ), o paskutinès treniruotès metu užfiksuotas skirtumas tarp geriausiai ir prasčiausiai šokinejjančiu mergaičiu rezultatų - $13 \mathrm{~cm}$ (nuo 21 iki $34 \mathrm{~cm}$ ). Matyti, kad visų mergaičių šuolių rezultatų vidurkiai buvo pagerinti dèl treniravimosi.

Tyrimo rezultatai, pateikti 6 paveiksle, rodo, kad mergaičių šuolių rezultatų standartinio nuokrypio duomenys didèja banguotai. Po šoklumo ugdymo standartinis nuokrypis išaugo nuo $1,9 \mathrm{iki}$ 3,3. Tikejjomès glaustesnių rezultatų.

Analizuojant tris galutinius geriausius ir blogiausius vertikalių šuolių rezultatus (7 pav.) matyti, kad visi mergaičių šuolių rezultatai gerejjo nuosekliai ir visos tyrimo dalyvės pagerino savo asmeninius vertikalaus šuolio rezultatų vidurkius. Pirmos treniruotès lyderès išlaikè savo pozicijas iki galo. Ju pavyti autsaiderèms nepavyko. Jei lyderès savo asmeninius rezultatus pagerino 9$10 \mathrm{~cm}$, tai silpniau šokančios mergaitės - nuo 1,1 iki $7,4 \mathrm{~cm}$, lyginant su pirma treniruote.

Tyrimo metu stebint mergaičių vertikalių šuolių aukščio prieaugio rezultatus ir lyginant juos su praejusios treniruotès rezultatais, pastebimas

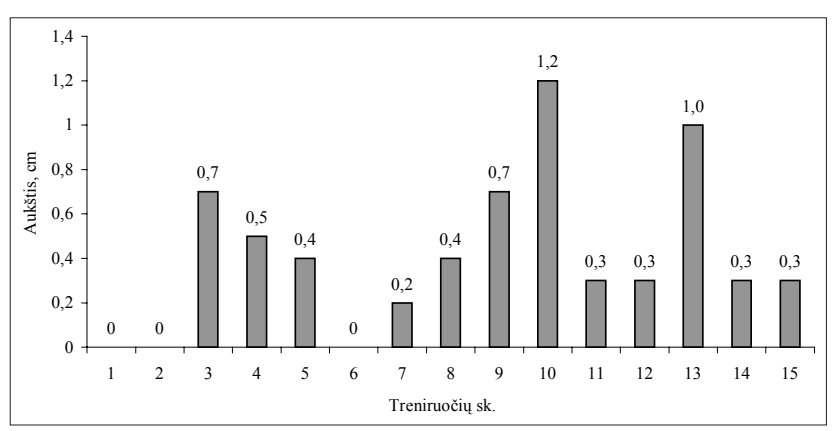

8 pav. Mergaičių šuolių rezultatų vidurkių prieaugis $\mathbf{c m}$, lyginant su praèjusios treniruotės rezultatais

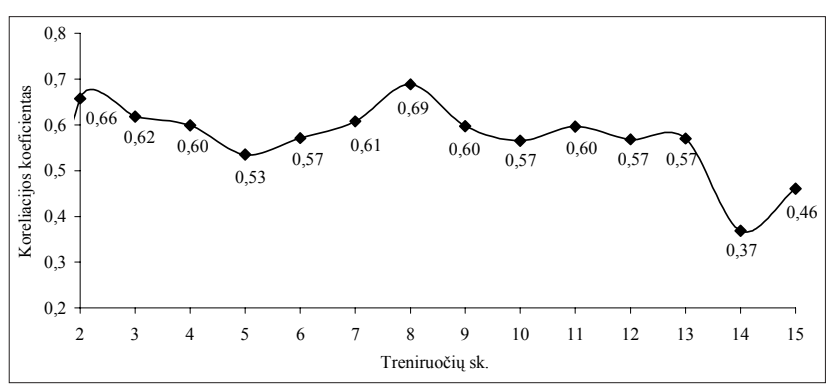

9 pav. Mergaičį̣ vertikalių šuolių koreliacija tarp pirmos ir kitų treniruočių reguliarus aukščio rezultatų gerejjimas. Tik per antrą ir šeštą treniruotę nepavyko pagerinti ankstesnių rezultatų. Šuolių rezultatų vidurkių rodikliai daugiau nei puse centimetro pagerinti trečios ir devintos treniruotes metu, net centimetru pagerinti 10 ir 13 treniruoteje ( 8 pav.).

Pastebèta mergaičių vertikalių šuolių rezultatu koreliacijos tiesioginè priklausomybè tarp pirmos ir kitų treniruočių (9 pav.), nuo antros iki tryliktos treniruotès matome vidutini koreliacini ryši. Tik paskutinèse treniruotèse pastebimas silpnas koreliacinis ryšys (tiesioginè priklausomybė). Koreliacijos koeficientas mažèja, todèl galima teigti, kad iš pirmos treniruočiu dienos šuoliu aukščio negalima prognozuoti paskutinès treniruotès rezultatų.

\section{REZULTATŲ APTARIMAS}

Tyrimo rezultatai parode, kad aštuonių savaičių trukmès vertikalaus šuolio krūviai reikšmingai padidina šoklumą. Sporto pedagogai ir mokslininkai, tiriantys šoklumo ugdymo priemonių bei metodų efektyvumą, pastebi, kad ugdant šoklumą gereja greitumo ir raumenų galingumo rodikliai. Tiek tyrimo pradžioje, tiek pabaigoje visų mergaičiu vertikalaus šuolio aukštis buvo skirtingas. Šuolio aukštị lemia labai daug veiksnių. Vertikalus šuolis yra vientisas lokomocinis judesys ir jo atlikimas, kaip teigia kai kurie mokslininkai, priklauso nuo vienos motorinès programos (Schmidth, 1988). Maždaug trečiais gyvenimo metais susiformuoja pagrindinès šuolio atlikimo motorinès programos ypatybès, o tolesniais ontogenezès tarpsniais ji tik tobulèja. Tačiau motorinè programa, kaip ir kiti refleksiniai bei raumeniniai mechanizmai, gali būti modifikuojami priklausomai nuo šuolio būdo, mokèjimo ji atlikti bei susikaupimo laipsnio (Schmidt, 1988; Komi, 1992). Šuolio amortizuojamai pritupiant (hp 90) aukštis priklauso nuo gebejjimo panaudoti elastinę raumenų energiją ir tempimo refleksą. Toks gebèjimas priklauso nuo raumenu kompozicijos greiti sportininkai geriau panaudoja elastinę energiją greitai ir lengvai amortizuojamai pritūpdami, o lèti - lètai ir smarkiai (Komi, 1992). Taigi, aiškinantis vaikų šoklumo skirtumus, būtina atsižvelgti į registruojamo šoklumo rodiklio specifiką, nes vienų šoklumas labiau priklauso nuo genetinių veiksnių, kitų - nuo ugdymo pobūdžio. Nors mes netyrème raumenu kompozicijos, manome, kad šoklesni yra iš prigimties stipresni vaikai arba tie, kuriu raumenyse vyrauja greitosios RS. Tai pa- 
tvirtina ir kiti autoriai (Jaščaninas ir kt., 1989; Häkkinen, 1994). Puberteto metu vaikų fizinis parengtumas labai priklauso nuo biologinio brendimo laipsnio (Malina and Bouchard, 1991). Testosterono kiekis kraujo plazmoje koreliuoja su raumenų maksimaliaja jèga (Kraemer \& Feck, 1993), o pubertatiniu laikotarpiu daugeja testosterono (Malina, Bouchard, 1991). Tai skatina raumenų jègos augimą ir lavejjimą. Mūsų tyrimo metu nebuvo matuojamas testosterono kiekis kraujyje, tačiau tai, kad tiriamujų biologinis amžius buvo panašus, leidžia teigti, jog šis veiksnys negali būti svarbiausias vertinant vaiku šoklumo rodiklių nevienodumą. Tačiau su vaikų augimu ir lytiniu brendimu susiję motorikos ypatumai gali labai veikti tiriamuju šoklumo kaitą.

Manytume, kad mergaičių šoklumas reikšmingai pagerèjo, lyginant su pirmų treniruočių rezultatais. Didelę ịtaką turèjo reguliarūs šoklumą ugdantys krūviai - rezultatai reguliariai treniruojantis tolygiai gerejo (matyt, išmokta geriau atlikti šuoli). Yra nustatyta, kad net per kelias treniruotes padidèja valingoji raumens susitraukimo jèga, nes išmokstama geriau atlikti judesi (Sale, 1988; Schmidt, 1988). Kaip matyti iš tyrimo duomenų, visos moksleivès reikšmingai pagerino vertikaliu šuolių rezultatus. Tai patvirtina ir (Balsom et al., 1992; Glenmark et al., 1992; Kommi, 1992) organizmo adaptacijos prie fizinių krūvių dèsningumai.

Skirtumas tarp silpniausiai ir geriausiai šokančiujų dar labiau išaugo, manytume, dèl to, kad jaunesniojo mokyklinio amžiaus mergaitès skirtingai reagavo i̇ mūsų skirtą fizinị krūvị. Tai, ko gero, lemia psichologiniai veiksniai — kaip moksleivis geba reikiamai susikaupti, ar turi motyvaciją. Dèl šios priežasties didèja motoneuronu impulsavimo dažnis, vyksta jų mobilizaciją skatinantys procesai, didejja motoneuronų aktyvumo sinchronizacija (Schmidt, 1988). Nuo motorinès programos tikslumo priklauso agonistų, sinergetų, antagonistų, rankų ir kojų raumenų koordinacija, kuri padeda geriau atlikti šuoli (Schmidt, 1988;
Skurvydas ir kt., 1988). Daug ką lemia: raumenų kompozicija - kuo daugiau raumenyse yra greitai susitraukiančių raumeninių skaidulų, tuo geresnis tiriamujų šoklumas (Häkkinen, 1994); raumens susitraukimo ilgis; greitujų raumeninių skaidulu hipertrofija (Goldspink, 1992); raumenu ir sausgysliu elastingumas (Bosco et al., 1983 b); raumeninių sausgyslių prisitvirtinimo kampas (Enoka, 1994).

Tyrimo rezultatai parode, kad aštuonių savaičių trukmès vertikalaus šuolio krūviai nors ir reikšmingai padidina šoklumą, bet iš pradiniu rezultatų negalima nustatyti, prognozuoti galutiniu. Kiekvienu amžiaus tarpsniu šoklumą lemia skirtingi veiksniai ir priklauso nuo specifiniu treniruotès krūvių. Tai gali klaidinti trenerius, bandančius prognozuoti mergaičiu raumenu staigiosios jègos galimybes. Biologiškai mažiau subrendęs vaikas dažnai dẻl neišvystytos raumenų jègos treneriams atrodo neperspektyvus. Šoklumo realizavimo komponentai organizmui vystantis bręsta netolygiai (Skurvydas ir kt., 1988). Iš vertikalių šuoliu aukščio tyrimo pradžioje negalime prognozuoti šuolių rezultatų treniruočiu pabaigoje.

\section{IŠVADOS}

1. Mergaičių šoklumas dèl nuoseklių treniruočių reikšmingai pagerejo, palyginti su pirma treniruote.

2. Du mėnesius ugdant jaunesniojo mokyklinio amžiaus mergaičiu šoklumą, šuolių rezultatai didèjo tolygiai.

3. Mergaičiu bendra vertikalių šuolių rezultatų vidurkių sklaida dèl treniruočių padidèjo.

4. Atlikus tyrimą nustatyta, kad iš pirmos treniruotės rezultatų negalima prognozuoti vertikalių šuoliu galutinių rezultatu. Vaiko organizmas yra dinamiška, nuolatos kintanti sistema, todèl negalima tiksliai nusakyti jo tolimesniu sportinių rezultatų.

\section{LITERATŪRA}

Balsom, P. D., Seger, J. Y., Sjodin, B. \& Ekblom B. (1992). Physiological responses to maximal intensity intermittent exercise. European Journal of Applied Physiology, 65, 144-149.

Booth, F. W. \& Thomason, D. B. (1991). Molecular and cellular adaptation of muscle in response to exercise: perspectives of various models. Physiology Review, $71(2), 541-585$.
Bosco, C., Komi, P. V., Tihanyi, J., Fekete, G. \& Apor, P. (1983 a). Mechanical power test and fiber composition of human leg extensor muscles. European Journal of Applied Physiology, 51 (1), 129-135.

Bosco, C., Luhtanen, P. \& Komi, P. V. (1983 b). A simple method for measurement of mechanical power in jumping. European Journal of Applied Physiology, 50 (2), 273282. 
Enoka, R. M., Stuart, D. G. (1992). Neurobiology of muscle fatigue. Journal of Applied Physiology, 72, $1631-1648$.

Glenmark, B., Hedberg, G., Jansson, E. (1992). Changes in muscle fiber type from adolescence to adulthood in women and men. Acta Physiologica Scandinavica, 146, 251-259. Goldspink, G. (1992). Cellular and Molecular Aspects of Adaptation in Skeletal Muscle. Oxford. P. 211-230.

Häkkinen, K. (1994). Neuromuscular adaptation during strength training, aging, detraining and immobilization. Critical Review in Physical and Rehabolation Medicine, 6 (3), 161-198.

Jaščaninas, J., Skurvydas, A., Mamkus, G. ir Ratkevičius, A. (1989). Ivairaus kryptingumo treniruočių krūviai, raumens susitraukimo greičio jègos ypatybès ontogenezè ir sportinès atrankos aspektai. Sveikatos apsauga, 6, 24-29.

Karoblis, P. (1999). Sporto treniruotes teorija ir didaktika. Vilnius.

Komi, P. V. (1992). Strength and Power in Sport. Oxford. Kraemer, W. J. \& Fleck, S. J. (1993). Strength Training for Young Athletes. Champaign, IL: Human Kinetics.

Malina, R. M., Bouchard, C. (1991). Growth, Maturation and Physical Activity. Champaigin, IL: Human Kinetics.
Mamkus, G. (1998). Amžiaus ir treniruotès poveikis koju raumenu susitraukimo ir atsipalaidavimo savybems: biomedicinos mokslu daktaro disertacijos santrauka. Kaunas.

Salmons, S. (1994). Exercise, stimulation and type transformation of skeletal muscle. International Journal of Sports Medicine, 15 (5), 136-141.

Schmidt, R. A. (1988). Motor Control and Motor Learning. Champaign, IL: Human Kinetics.

Skurvydas, A., Stasiulis, A. ir Vilčinskas, P. (1988). Šoklumo fiziologiniai pagrindai. Vilnius.

Spirduso, W. W. (1995). Physical Dimensions of Ageing. Human Kinetics.

Stanislovaitis, A. (1998). Influence of specialized strength, sprint and endurance training loads on adaptation characteristics of the function of human skeletal muscles. Summary of doctoral dissertation: biomedical sciences, biology (01B). Kaunas.

Wilmore, J. H. \& Costill, D. L. (1994). Physiology of Exercise and Sport. Champaign, IL: Human Kinetics.

Zachovajevas, P. (1998). Raumenu mažu dažniu nuovargis atliekant fizinius pratimus maksimaliu intensyvumu: daktaro disertacija. Kaunas: LKKI.

\title{
SPRING DYNAMICS OF THE JUNIOR SCHOOL AGED GIRLS DURING TWO-MONTHS TRAINING
}

\author{
Eduardas Rudas, Albertas Skurvydas \\ Lithuanian Academy of Physical Education, Kaunas, Lithuania
}

\begin{abstract}
The study is about spring dynamics among junior school aged girls. 10-year-old children's spring was trained during two months. 17 girls learning at the fourth form took part in the research. The aim of the research was to test the dynamics of the spring of the junior school aged girls by training their spring for 2 months. Spring was trained for 2 months twice a week. During the exercises after the low intensity 10-minute warming-up girls used to make 50 springs every 30 seconds. It was recommended to spring as high as possible. To measure the level of a spring the contact platform was used. It was connected with the electronic meter of a spring that measured a spring's height and the take-off time. The results of girls' springs were recorded into the individual springs' protocol. Using the methods of statistical mathematics the results of the research were analysed. After the 2-month testing of the junior school aged girls' springs it was found out that the girls' springs were influenced by the training and considerably improved comparing with the first training. The girls' results improved gradually and also the research showed that after the exercises the dispersal of girls' springs increased. As it was showed by the test, it is impossible to foresee the final results of the springs after the first average results of the vertical spring.
\end{abstract}

Keywords: stretch-shortening cycle, muscle contraction, physical education.

Gauta 2004 m. lapkričio 3 d.

Received on November 3, 2004

Priimta $2005 \mathrm{~m}$. vasario $2 \mathrm{~d}$.

Accepted on February 2, 2005
Eduardas Rudas

Lietuvos kūno kultūros akademija

(Lithuanian Academy of Physical Education)

Sporto g. 6, LT-44221 Kaunas

Lietuva (Lithuania)

Tel +3702701431

E-mail e.rudas@1kka.lt 